\title{
Effects of autologous bone marrow-derived stem cell mobilization on acute tubular necrosis and cell apoptosis in rats
}

\author{
LINGYUN BI ${ }^{1}$, GUOHONG WANG ${ }^{2}$, DASHENG YANG ${ }^{1}$, SHUJUN LI $^{1}$, BIN LIANG $^{1}$ and ZIMING HAN ${ }^{1}$ \\ ${ }^{1}$ Department of Pediatrics, The First Affiliated Hospital of Xinxiang Medical University, Weihui, Henan 453100; \\ ${ }^{2}$ Laboratory of Physiology, Xinxiang Medical University, Xinxiang, Henan 453000, P.R. China
}

Received April 19, 2014; Accepted December 1, 2014

DOI: $10.3892 /$ etm.2015.2592

\begin{abstract}
The aim of this study was to investigate the effects of stem cell factor (SCF) and granulocyte colony-stimulating factor (G-CSF) on bone marrow-derived stem cell (BMSC) mobilization in rat models of renal ischemia/reperfusion (I/R) injury. In addition, the effects of SCF and G-CSF on cellular apoptosis were explored in order to determine the protective mechanism of the two factors against renal I/R injury. A unilateral renal I/R injury model was established for the model and treatment groups. The treatment and treatment control groups were subcutaneously injected with SCF (200 $\mu \mathrm{g} / \mathrm{kg} /$ day) and $\mathrm{G}-\mathrm{CSF}(50 \mu \mathrm{g} / \mathrm{kg} /$ day) $24 \mathrm{~h}$ after the establishment of the model for five consecutive days. The total number of leukocytes in the peripheral blood and the cellular percentages of cluster of differentiation (CD) $34^{+}$, renal $\mathrm{CD} 4^{+}$and apoptotic cells were detected. The total number of leukocytes in the peripheral blood and the percentages of $\mathrm{CD} 34^{+}$cells in the treatment and treatment control groups reached maximum levels on the fifth postoperative day and were significantly higher than those in the normal control and model groups. The number of renal $\mathrm{CD} 34^{+}$cells in the treatment group was significantly increased compared with that in the treatment control and model groups. The apoptotic indices (AIs) of the model and treatment groups were higher than those of the normal control and treatment control groups. The AI of the model group was significantly higher than that of the treatment group. In conclusion, the combined application of SCF and G-CSF can mobilize sufficient numbers of BMSCs and cause cellular 'homing' to the injured site, thus inhibiting apoptosis and promoting the repair of renal tubular injury.
\end{abstract}

Correspondence to: Dr Dasheng Yang, Department of Pediatrics, The First Affiliated Hospital of Xinxiang Medical University, 88 Jiankang Road, Weihui, Henan 453100, P.R. China

E-mail: dashengyangcn@163.com

Key words: acute tubular necrosis, bone marrow-derived stem cells, granulocyte colony-stimulating factor, stem cell factor, apoptosis

\section{Introduction}

Acute tubular necrosis (ATN) is the main cause of acute kidney injury (AKI), and the incidence of AKI in hospitalized patients has previously been reported as $2.41 \%$ (1). As such, the prevention and treatment of ATN is a major concern in the medical field. Blood purification therapy is the only remedial treatment for ATN once it occurs. This therapy replaces the work of kidneys to maintain a stable environment for the body until the renal tubular epithelial cells are able to repair themselves (1-3). When the renal tube is damage beyond complete repair, chronic renal failure may occur; patients with renal failure require a lifelong dependence on blood purification therapy or kidney transplantation. The prognosis of renal failure is not highly optimistic, and no drug or method to promote the repair of necrotic renal tubules or cure tubular necrosis has yet been determined.

Recent studies have shown that bone marrow-derived stem cell (BMSC)-mobilizing agents, such as granulocyte colony-stimulating factor (G-CSF) and stem cell factor (SCF), can mobilize autologous BMSCs to treat a variety of diseases, including kidney damage, myocardial necrosis, nerve and liver damage, and hematological malignancies (4-8). The flexibility of BMSCs presents a potential route for the treatment of renal failure.

Under normal circumstances, few BMSCs are known to enter the peripheral blood; therefore, the effect of these cells on the repair of renal tubular necrosis is limited. G-CSF and SCF can drive more BMSCs into the peripheral blood, thereby meeting the requirements for the treatment of renal failure (9). In the present study, a combinatorial treatment of G-CSF and SCF was administered, and the effects of the treatment on BMSC mobilization and cell apoptosis were observed in an ATN rat model. The aim of the study was to explore the roles of SCF and G-CSF in the promotion of ATN repair.

\section{Materials and methods}

Reagents. Recombinant human G-CSF injection (product name, Ji Sai Xin; batch no. 200804Y21) was purchased from NCPC GeneTech Biotechnology Development Co., Ltd. (Shijiazhuang, China), and SCF (batch no. 20080405) was obtained from Chengdu Diao Jiuhong Pharmaceutical Factory (Chengdu, China). Apoptosis kits (cat. no. 11684817910) were 
purchased from Roche (Indianapolis, IN, USA), and the rabbit anti-rat cluster of differentiation (CD)34 polyclonal antibody (cat. no. bs-0754R) and ready-to-use Streptavidin-Peroxidase immunohistochemistry kit (cat. no. SP-0023) were obtained from Beijing Bioss Biosynthesis Biotechnology Co., Ltd. (Beijing, China).

Establishment of animal models and grouping. The present study was approved by the ethics committee of The First Affiliated Hospital of Xinxiang Medical University (Weihui, China). All animal experiments conformed to the Ethical Issues in Animal Experimentation guidelines (2009) (10). A total of 128 healthy male Sprague Dawley rats, weighing 250-280 g and aged 8-10 weeks, were provided by the Experimental Animal Center of Zhengzhou University (Zhengzhou, China). The rats were separately housed and fed ad libitum. Urine screening of the rats was completed, and rats that obtained negative results during the screening were randomly divided into four groups: Normal control, model, treatment and treatment control. Each group comprised 32 rats. The model and treatment groups were used to establish the unilateral renal ischemia/reperfusion (I/R) injury model according to the method described by Supavekin et al (11). The treatment group was subcutaneously injected with SCF $(200 \mu \mathrm{g} / \mathrm{kg}$, once/day) and G-CSF (50 $\mu \mathrm{g} / \mathrm{kg}$, once/day) for five consecutive days $24 \mathrm{~h}$ after modeling. Normal rats in the treatment control group were injected with SCF and G-CSF at the same time-points and with the same doses. The SCF and G-SCF doses injected into the rats were based on those described in the literature (12). Since BMSC mobilization causes a peak in the peripheral $\mathrm{CD} 34^{+}$cell population 3-5 days after treatment (13), the fifth day post-intervention day was selected as the starting time-point of detection.

Specimen collection. Eight rats were randomly selected from each group to complete specimen collection on the fifth, 10th, 17th and 24th days post-treatment, respectively. Chloral hydrate solution (10\%) at a dose of $3.5 \mathrm{ml} / \mathrm{kg}$ was intraperitoneally injected into the rats as anesthesia, and venous blood samples $(2 \mathrm{ml})$ were obtained and preserved in EDTA-coated Eppendorf tubes. The left kidney of the rats was removed, washed with saline and then cut into pieces measuring $1.0 \times 1.0 \times 0.2 \mathrm{~cm}$; the resultant tissues were fixed in $10 \%$ neutral formalin buffer.

Extraction of peripheral blood CD34 ${ }^{+}$cells. Ficoll-Hypaque density gradient centrifugation was performed to isolate the mononuclear cells from the peripheral blood (14). Firstly, peripheral blood extraction of $\mathrm{CD} 34^{+}$cells was completed by fold-diluting $\sim 2 \mathrm{ml}$ venous blood with Hank's solution (Sigma-Aldrich, St. Louis, MO, USA), prior to mixing. Ficoll-Hypaque lymphocyte separation medium (MP Biomedicals, Santa Ana, CA, USA) was then added to the blood via the tube wall, and the blood was centrifuged at $700 \mathrm{x}$ g for $20 \mathrm{~min}$. Mononuclear cells located in the tunica albuginea were subsequently pipetted from the blood using a capillary tube and placed in another sterile tube. The blood was washed with $2 \mathrm{ml}$ Hank's solution and then centrifuged twice at $400 \mathrm{x} \mathrm{g}$ for $10 \mathrm{~min}$. The supernatant was discarded. Subsequent to discarding the supernatant, RPMI-1640 containing 10\% fetal calf serum (HyClone Laboratories, Inc., Logan, UT, USA) was added to the blood to resuspend the cells. A drop of the cell suspension and a drop of $0.2 \%$ trypan blue dye were mixed. The total cell numbers were then counted within four large squares, and the concentration of mononuclear cells was calculated using the following formula: Concentration of mononuclear cells (cell number $/ \mathrm{ml}$ cell suspension $)=$ total cell numbers in the four large squares/4 x 104 × 2 (dilution factor).

Flow cytometry. Fluorescein isothiocyanate-CD34+ monoclonal antibody $(\sim 100 \mu \mathrm{l}$; R\&D Systems, Inc., Minneapolis, MN, USA) was added and mixed for monoclonal antibody labeling in the dark at room temperature for $25 \mathrm{~min}$. The antibody was then centrifuged twice in $1 \mathrm{ml}$ phosphate-buffered saline (PBS) at $350 \mathrm{x}$ g for $5 \mathrm{~min}$. Following centrifugation, $\sim 0.5 \mathrm{ml} 1 \%$ paraformaldehyde was used to resuspend the cells. Flow cytometry was used to detect the fluorescence of the cells. Exactly 105 cells were counted from each tube to detect the $\mathrm{CD} 34^{+}$cells and the percentage was analyzed. The negative control group was treated in the same manner during this experiment.

Terminal deoxynucleotidyl transferase-mediated dUTP nick end labeling (TUNEL) method. Paraffin sections $(4-\mu \mathrm{m})$ were conventionally dewaxed using $\mathrm{H}_{2} \mathrm{O}_{2}-\mathrm{CH}_{3} \mathrm{OH}$ solution $(0.3 \%)$ for $5 \mathrm{~min}$ at room temperature. PBS $(0.01 \mathrm{~mol} / \mathrm{l})$ was then used to wash the cells, and proteinase $\mathrm{K}(20 \mathrm{mg} / \mathrm{l}$; Sigma-Aldrich) was used to treat and incubate the cells at $37^{\circ} \mathrm{C}$ for $30 \mathrm{~min}$. The cells were subsequently washed with $0.01 \mathrm{~mol} / \mathrm{l}$ PBS. Exactly $50 \mu \mathrm{l}$ TUNEL reaction mixture (cat. no. 11684817910; Roche) was added to the cells, prior to incubation for $1 \mathrm{~h}$ at $37^{\circ} \mathrm{C}$. The cells were then washed once more with $0.01 \mathrm{~mol} / 1 \mathrm{PBS}$. A total of $\sim 50 \mu \mathrm{l}$ converter-POD solution (Roche) was added to the cells, and incubation was performed at $37^{\circ} \mathrm{C}$ for $1 \mathrm{~h}$. Following incubation, the cells were further washed with $0.01 \mathrm{~mol} / 1$ PBS. 3,3'-Diaminobenzidine staining, hematoxylin re-staining, ethanol-hydrochloride differentiation, gradient ethanol dehydration, xylene hyalinization, neutral gum closure and microscopic observation were subsequently performed.

Calculation of the apoptotic index (AI). The numbers of positive cells in 10 consecutive high-power fields were observed under an ordinary optical microscope (magnification, x200). The cells were then counted to calculate the percentage of apoptotic cells among the total tubular epithelial cells, i.e. the AI (\%) of the renal tubular epithelial cells.

Immunohistochemistry. The streptomycin avidin-biotin-peroxidase complex method (cat. no. SP-0023; Beijing Bioss Biosynthesis Biotechnology Co., Ltd.) was used for the immunohistochemical staining. The paraffin sections $(4-\mu \mathrm{m})$ were conventionally dewaxed and hydrated, prior to undergoing microwave antigen retrieval with citrate buffer. The sections were incubated at $98^{\circ} \mathrm{C}$ for $5 \mathrm{~min}$ and then at $20^{\circ} \mathrm{C}$ for a further 5 min, followed by closure with $5 \%$ bovine serum albumin. Rabbit anti-rat CD34+ polyclonal antibody (dilution, 1:200; cat. no. bs-0754R; Beijing Bioss Biosynthesis Biotechnology Co., Ltd.) was used as the primary antibody for overnight incubation at $4^{\circ} \mathrm{C}$. Subsequent to washing with PBS, goat anti-rabbit 
Table I. Number of white blood cells in the peripheral blood $\left(\mathrm{x} 10^{9} / \mathrm{l}\right)$ and the ratio of $\mathrm{CD} 34^{+}$cells among the mononuclear cells $(\%)$.

\begin{tabular}{|c|c|c|c|c|c|c|}
\hline \multirow[b]{2}{*}{ Time (days) } & \multirow[b]{2}{*}{ Index } & \multirow[b]{2}{*}{$\mathrm{N}$} & \multicolumn{4}{|c|}{ Group } \\
\hline & & & Normal control & Model & Treatment & Treatment control \\
\hline \multirow[t]{2}{*}{5} & Leukocyte & 8 & $5.410 \pm 0.325$ & $5.641 \pm 1.921$ & $18.388 \pm 3.224^{\mathrm{a}}$ & $13.340 \pm 3.309^{\mathrm{a}}$ \\
\hline & $\mathrm{CD} 34^{+}$cells & 8 & $4.865 \pm 4.066$ & $6.579 \pm 4.103$ & $11.848 \pm 3.021^{\mathrm{a}}$ & $9.585 \pm 1.054^{\mathrm{a}}$ \\
\hline \multirow[t]{2}{*}{10} & Leukocyte & 8 & $5.400 \pm 1.032$ & $5.828 \pm 2.493$ & $9.738 \pm 4.136^{\mathrm{a}}$ & $8.970 \pm 0.467$ \\
\hline & $\mathrm{CD} 34^{+}$cells & 8 & $4.705 \pm 2.496$ & $5.949 \pm 3.441$ & $10.760 \pm 4.806^{\mathrm{a}}$ & $8.235 \pm 1.435$ \\
\hline \multirow[t]{2}{*}{17} & Leukocyte & 8 & $5.475 \pm 0.587$ & $6.115 \pm 2.109$ & $7.494 \pm 2.680$ & $6.430 \pm 1.032$ \\
\hline & $\mathrm{CD} 34^{+}$cells & 8 & $4.505 \pm 2.157$ & $5.578 \pm 3.495$ & $5.789 \pm 1.589$ & $4.980 \pm 4.186$ \\
\hline \multirow[t]{2}{*}{24} & Leukocyte & 8 & $5.495 \pm 0.219$ & $5.896 \pm 1.821$ & $6.573 \pm 2.354$ & $5.410 \pm 0.438$ \\
\hline & $\mathrm{CD} 34^{+}$cells & 8 & $4.225 \pm 0.247$ & $4.013 \pm 1.413$ & $4.300 \pm 1.779$ & $4.775 \pm 2.991$ \\
\hline
\end{tabular}

Results are presented as the mean \pm standard deviation. Compared with the control and model groups, ${ }^{\mathrm{a}} \mathrm{P}<0.05$. CD, cluster of differentiation.

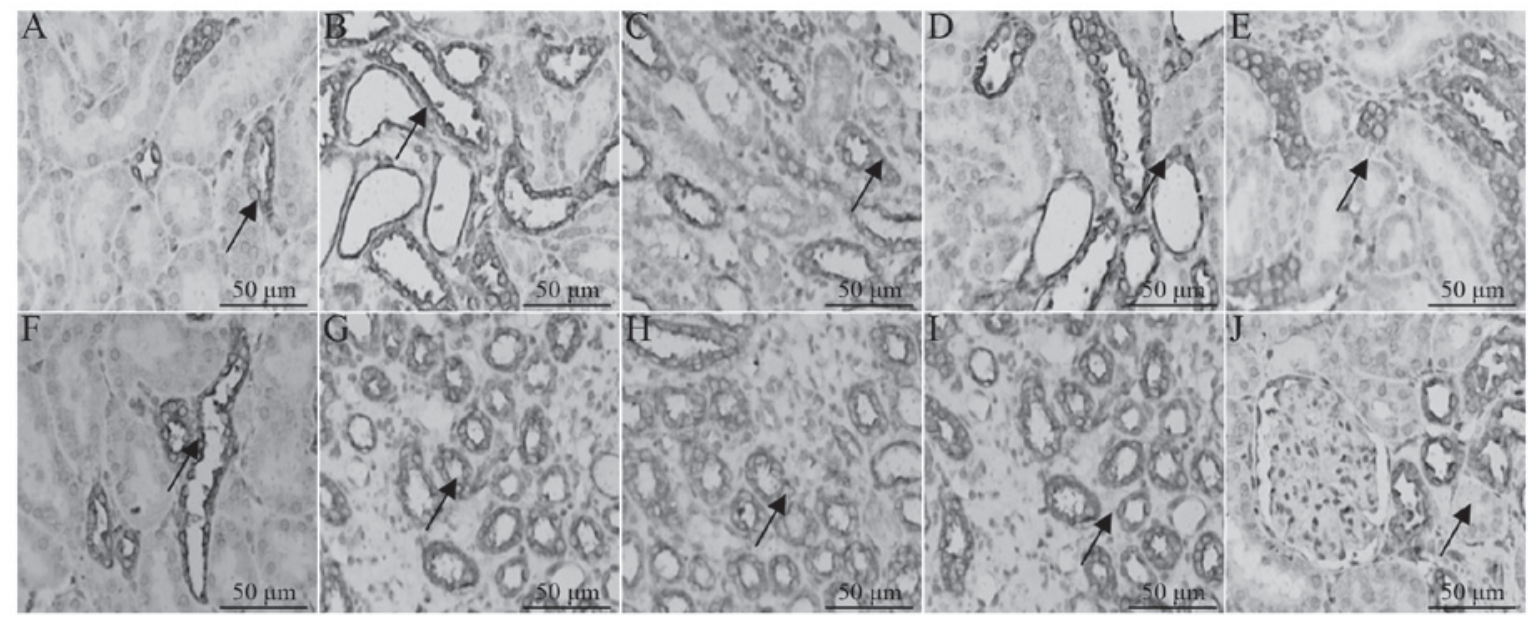

Figure 1. Number of cluster of differentiation $34^{+}$cells in four groups of rat renal tissues (arrows indicate immunohistochemical staining; magnification, $\mathrm{x} 200$ ). (A-C) The (A) normal control, (B) treatment control and (C) model groups at day 5; (D-F) the model group at (D) day 10, (E) day 17 and (F) day 24 ; (G-J) the treatment group at $(\mathrm{G})$ day $5,(\mathrm{H})$ day $10,(\mathrm{I})$ day 17 and $(\mathrm{J})$ day 24.

immunoglobulin G (dilution, 1:500; Zhongshan Goldenbridge Biotechnology Co., Ltd., Beijing, China) was added as a second antibody and incubation continued at $37^{\circ} \mathrm{C}$ for $30 \mathrm{~min}$. The sections were stained subsequent to washing with PBS. PBS was used instead of the primary antibody in the control group.

Evaluation of immunohistochemical results. Brown tissues or areas with brown granular deposition were observed as positively stained areas under a light microscope; 10 non-overlapping view fields of each slice were randomly selected at x200 magnification. An IDA-2000 computer image automatic analyzer (Olympus Corporation, Tokyo, Japan) was used to analyze the positive immunohistochemical signals in the selected fields of view.

Statistical analysis. All data are expressed as the mean \pm standard deviation. The Student's t-test was used for intergroup comparisons, while Spearman's correlation was used to analyze and process inter-index associations. SPSS software (version 13.0; SPSS, Inc., Chicago, IL, USA) was used for the statistical analysis, and $\mathrm{P}<0.05$ was considered to indicate a statistically significant difference.

\section{Results}

Changes in total peripheral blood leukocyte numbers and percentages of $\mathrm{CD}_{3} 4^{+}$cells. The total peripheral blood leukocyte numbers and percentages of $\mathrm{CD} 34^{+}$cells in the treatment and treatment control groups peaked on the fifth postoperative day compared with the normal control and model groups. The difference in these indices among the groups was statistically significant $(\mathrm{P}<0.05)$. The total peripheral blood leukocyte numbers and percentages of $\mathrm{CD} 34^{+}$cells gradually decreased on the 10th postoperative day, although significant differences remained between the treatment and model groups $(\mathrm{P}<0.05)$. On the 17th and 24th postoperative days, the differences among the experimental groups showed no statistical significance ( $\mathrm{P}>0.05)$. Comparisons between the model and normal control groups revealed no statistically significant differences at all the time-points studied (Table I). 
Table II. Comparison of the apoptotic indices (\%) of renal tissues from four groups of rats.

\begin{tabular}{lccccc}
\hline & & \multicolumn{3}{c}{ Group } \\
\cline { 3 - 5 } Time (days) & $\mathrm{N}$ & Normal control & \multicolumn{1}{c}{ Model } & Treatment & Treatment control \\
\hline 5 & 8 & $0.440 \pm 0.113$ & $35.608 \pm 1.080^{\mathrm{a}}$ & $30.611 \pm 0.781^{\mathrm{a}, \mathrm{b}}$ & $0.465 \pm 0.078$ \\
10 & 8 & $0.485 \pm 0.007$ & $30.778 \pm 0.718^{\mathrm{a}, \mathrm{c}}$ & $20.876 \pm 1.207^{\mathrm{a}, \mathrm{b}, \mathrm{c}}$ & $0.475 \pm 0.007$ \\
17 & 8 & $0.495 \pm 0.050$ & $25.568 \pm 1.207^{\mathrm{a}, \mathrm{c}}$ & $5.536 \pm 0.698^{\mathrm{a}, \mathrm{b}, \mathrm{c}}$ & $0.440 \pm 0.085$ \\
24 & 8 & $0.490 \pm 0.028$ & $8.493 \pm 1.044^{\mathrm{a}, \mathrm{c}}$ & $3.869 \pm 0.359^{\mathrm{a}, \mathrm{b}, \mathrm{c}}$ & $0.475 \pm 0.021$ \\
\hline
\end{tabular}

Results are presented as the mean \pm standard deviation. Compared with the normal control group at the same time-point, ${ }^{\mathrm{a}} \mathrm{P}<0.05$; compared with the model group at the same time-point, ${ }^{b} \mathrm{P}<0.05$; compared with the previous time-point of the same group, ${ }^{\mathrm{c}} \mathrm{P}<0.05$.

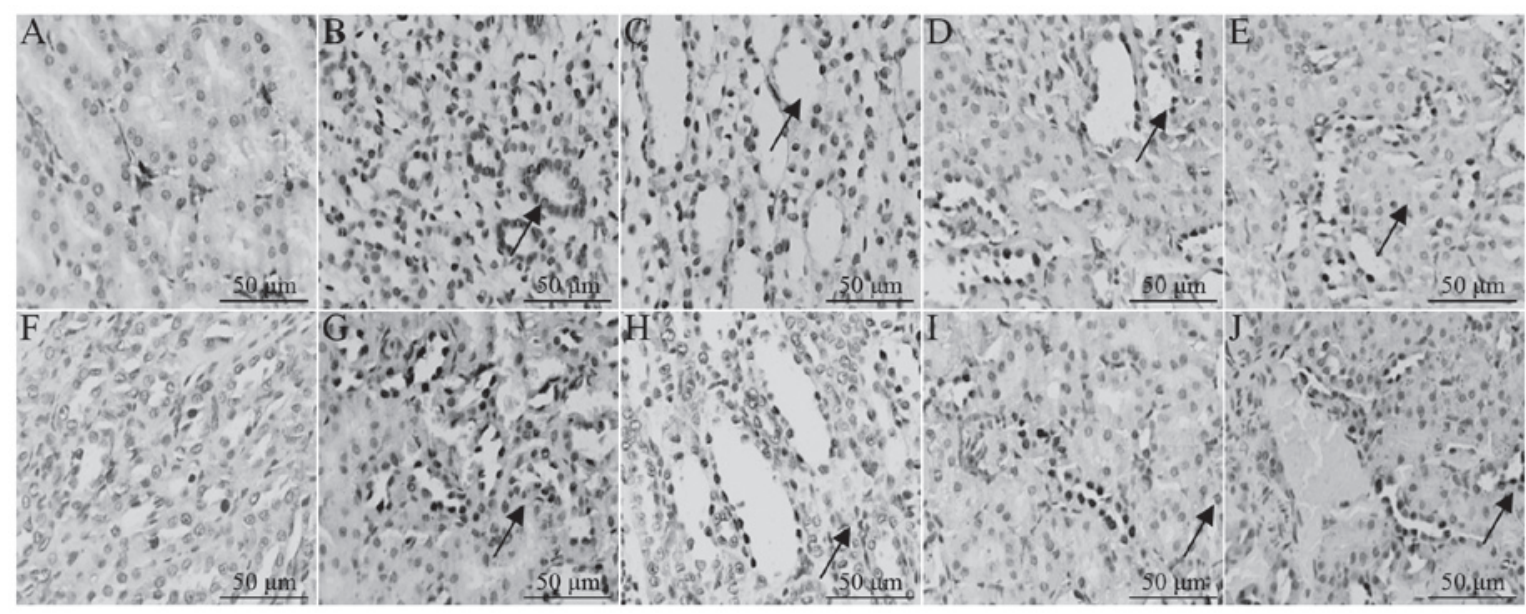

Figure 2. Number of apoptotic cells in four groups of rat renal tissues (arrows indicate terminal deoxynucleotidyl transferase-mediated dUTP nick end labeling staining; magnification, $x 200$ ). (A-C) The (A) normal control, (B) treatment control and (C) model groups at day 5; (D-F) the model group at (D) day 10, (E) day 17 and (F) day 24; (G-J) the treatment group at (G) day 5, (H) day 10, (I) day 17 and (J) day 24.

Expression of $\mathrm{CD} 34^{+}$cells in renal tissue. The number of $\mathrm{CD} 34^{+}$ cells in the renal tissue of the model and treatment groups was significantly increased on the fifth, 10th and 17th postoperative days compared with that in the normal and treatment control groups $(\mathrm{P}<0.05)$. The increase in the number of cells in the treatment group was more significant than that in the model group $(\mathrm{P}<0.05)$ at the same time-points. The $\mathrm{CD} 34^{+}$cells in the renal tissue of the treatment group reverted to their usual state on the 24th postoperative day, while the number of cells remained high in the model group. At this time-point, the differences among the groups were not statistically significant (Fig. 1).

Comparison of apoptosis and the AI in renal cells. The AIs of the model and treatment groups were higher than those of the normal control and treatment control groups $(\mathrm{P}<0.05)$. The AI of the model group was significantly higher than that of the treatment group $(\mathrm{P}<0.05)$. The level of apoptosis in the renal tubular epithelial cells decreased over time (Table II and Fig. 2).

\section{Discussion}

A common cause of ATN is renal I/R injury, which is associated with high rates of morbidity and mortality $(1,15)$. In recent years, significant clinical and laboratory studies have been performed to determine methods to treat ATN $(1,12,16,17)$.
In particular, the development of regenerative medicine has provided new avenues for the treatment of I/R injury.

BMSCs are multipotent stem cells. At least three types of BMSCs are known to exist in the bone marrow: Hematopoietic stem cells, endothelial progenitor cells (EPCs) and mesenchymal stem cells (18). The majority of studies have considered $\mathrm{CD} 34^{+}$cells as BMSCs; therefore, $\mathrm{CD} 34^{+}$ cells have been treated as the source cell marker of the biological activities and clinical applications of BMSC mobilization $(12,19,20)$. The differentiation of BMSCs exhibits a certain plasticity $(21,22)$; BMSCs can be horizontally differentiated into other types of tissue cells, including renal tubular epithelial cells. Such differentiation provides a new means of treating ATN.

The number of BMSCs in bone marrow is meagre under normal circumstances, with BMSCs accounting for only $0.01 \%$ of the cells in the tissue. This number is even lower and may be virtually undetectable in the peripheral blood (23). Several factors can promote significant increases in the number of BMSCs in peripheral blood via a process known as mobilization. Kale et al (9) demonstrated that renal ischemic injury can significantly increase the number of BMSCs in the circulatory system. Besides endogenous ischemia and injury, which mobilize EPCs, other BMSC mobilizing agents include G-CSF, granulocyte macrophage colony-stimulating factor 
(GM-CSF), SCF, vascular endothelial growth factor, angiopoietin-1, stromal cell-derived factor-1 and statins $(24,25)$. Zhang et al (26) demonstrated that the combination of G-CSF and SCF, which are normally found in advanced progenitor cells and early hematopoietic stem and primitive hematopoietic progenitor cells, respectively, may encourage BMSCs to enter the peripheral blood. The mobilizing effect of G-CSF and SCF is more significant than that induced by each factor alone. SCF is an acid glycoprotein generated by stromal cells inside the bone marrow microenvironment (27). SCF is important in the survival, proliferation, differentiation and adhesion of hematopoietic stem cells, EPCs and the bone marrow microenvironment $(28,29)$. SCF can combine various hematopoietic growth factors to promote and generate EPCs and increase the number of developing colonies. G-CSF is a growth factor that acts on advanced progenitor cells and promotes the resting stem cells into the cell cycle (25). $\mathrm{G}-\mathrm{CSF}$ also induces BMSCs to leave the bone marrow and enter the blood circulation by reducing the number of cell surface adhesion molecules (30). The synergistic effects of G-CSF and SCF depend on phosphatidylinositol 3-kinase and mitogen-activated protein kinase $(31,32)$. Signal transduction and transcription activator 3 could be the key factor in the downstream signal complement pathway of the SCF and G-CSF receptors $(33,34)$.

In the present study, the total numbers of leukocytes and percentages of $\mathrm{CD}_{3} 4^{+}$cells among the mononuclear cells in the peripheral blood were compared among four groups of rats at different time-points. Findings revealed that the total numbers of leukocytes and percentages of $\mathrm{CD} 34^{+}$cells in the treatment and treatment control groups peaked on the fifth postoperative day. Furthermore, the number of $\mathrm{CD} 34^{+}$cells in the peripheral blood positively correlated with the changes in the numbers of leukocytes; therefore, the combined application of G-CSF and SCF has significant mobilization effects on BMSCs, and these mobilization effects can be indirectly predicted by the number of leukocytes in the peripheral blood. Experimental results also showed that the number of $\mathrm{CD} 34^{+}$cells in the peripheral blood exhibited a slight increase following simple renal I/R injury, which indicates that the self-mobilization of BMSCs during ischemia is a self-repair reaction of the body in response to ischemic injury; however, this self-repairing function is very weak.

Mobilized BMSCs must directly migrate to the ischemic area to completely repair the damage. Chemotactic factors of BMSC surface receptors, as well as several cell adhesion molecules, can precisely control the 'homing' of the BMSCs (35). Leukocyte chemokines and adhesion molecules can also precisely control the chemotactic movement of inflammatory cells when inflammation occurs (36-38). Inflammation occurs in the ischemic area subsequent to renal I/R. The conditions that are considered important for the homing of BMSCs include the release of various inflammatory mediators, e.g. interferon- $\gamma$, interleukin (IL)-2, IL-10, GM-CSF and tumor necrosis factor- $\alpha$ (39); invasion of mononuclear granulocytes; activation of mast cells; degradation of extracellular matrix proteins; and expression of adhesion molecules in endothelial cells and renal tubular epithelial cells. Matrix metalloproteinase- 2 and slit homolog 3 protein have recently been identified as promoters of the release and homing of BMSCs from the bone marrow niche $(40,41)$.
The present study showed that the homing of BMSCs is directed towards injured tubules and that this homing is positively correlated with the number of CD $34^{+}$cells in the peripheral blood. Immunohistochemical results revealed that there were increased numbers of $\mathrm{CD} 34^{+}$cells in the model and treatment groups compared with the normal and treatment control groups. The increase in $\mathrm{CD} 34^{+}$cells in the treatment group, however, was notably more significant than that in the model group. The number of $\mathrm{CD} 34^{+}$cells in the normal and treatment control groups did not increase, which indicates that G-CSF and SCF promote increases in BMSCs in the peripheral blood. Renal tissue injury appears to be an important factor influencing the homing of BMSCs.

In a number of studies it has been suggested that BMSCs can be trans-differentiated into renal tubular epithelial cells under certain conditions, thereby contributing to the repair of renal tubular injury (9,42-44). Li et al (45) demonstrated that BMSCs could be trans-differentiated into renal tubular epithelial cells under various physiological and pathological conditions and that trans-differentiation rates were associated with the extent of damage in the renal tube. Despite this, the mechanism through which BMSCs are differentiated into renal tubular epithelial cells to promote the rehabilitation of renal tubular injury remains unknown. The mechanism presented in the study by Li et al (45) was unclear; however, it is believed that the microenvironment is the deciding factor underlying directional differentiation following the direct homing of BMSCs towards the damaged renal tube. Numerous active cellular factors, e.g. epidermal growth factor, hepatocyte growth factor, insulin-like growth factor-I, bone morphogenetic protein and erythropoietin, are important in the regeneration process of renal tubes (46-48).

The present study used the TUNEL method to detect apoptotic cells in rat renal tissues. The findings revealed that the numbers of apoptotic cells in the model and treatment groups were significantly higher at different time-points than those in the normal control and treatment control groups. The findings also showed that the number of apoptotic cells in the treatment group was significantly lower than that in the model group, which indicates that the experimental intervention could inhibit apoptosis, reduce renal I/R injury and promote the restoration of renal tubes.

In conclusion, the present study has demonstrated that the combined application of G-CSF and SCF to rat models of I/R injury can mobilize the release of BMSCs into the peripheral blood and directly allow cellular homing towards the injured renal tubes for restoration. Further studies are required to investigate the mechanism underlying the mobilization and homing of BMSCs, as well as the mechanisms involved in the BMSC-mediated renal tube repair.

\section{References}

1. Lu R, Muciño-Bermejo MJ, Armignacco P, et al: Survey of acute kidney injury and related risk factors of mortality in hospitalized patients in a third-level urban hospital of Shangai. Blood Purif 38: $140-148,2014$

2. FerreyraC,VargasF,Rodríguez-GómezI,etal: Preconditioning with triiodothyronineimprovestheclinicalsigns andacute tubularnecrosis induced by ischemia/reperfusion in rats.PLoS One 26: e74960,2013.

3. Hofmann CL and Fissell WH: Middle-molecule clearance at 20 and $35 \mathrm{ml} / \mathrm{kg} / \mathrm{h}$ in continuous venovenous hemodiafiltration. Blood Purif 29: 259-263, 2010. 
4. Jia X,Xie X,Feng G, et al: Bone marrow-derived cells can acquire renal stem cells properties and ameliorate ischemia-reperfusion induced acute renal injury. BMC Nephrol 13: 105, 2012.

5. Barile L, Cerisoli F, Frati G, et al: Bone marrow-derived cells can acquire cardiac stem cells properties in damaged heart. $\mathrm{J}$ Cell Mol Med 15: 63-71, 2011.

6. Osada T, Watanabe M, Hasuo A, et al: Efficacy of the coadministration of granulocyte colony-stimulating factor and stem cell factor in the activation of intrinsic cells after spinal cord injury in mice. J Neurosurg Spine 13: 516-523, 2010.

7. Takami T, Terai $\mathrm{S}$ and Sakaida I: Advanced therapies using autologous bone marrow cells for chronic liver disease. Discov Med 14: 7-12, 2012.

8. Shen WY, Li JY, Hong M, et al: Clinical study on high-dose etoposide with granulocyte colony-stimulating factor for mobilization of autologous peripheral blood stem cells in patients with hematologic malignancies. Zhonghua Xue Ye Xue Za Zhi 33: 628-631, 2012 (In Chinese).

9. Kale S, Karihaloo A, Clark PR, Kashgarian M, Krause DS and Cantley LG: Bone marrow stem cells contribute to repair of the ischemically injured renal tubule. J Clin Invest 112: 42-49, 2003.

10. Parodi AL: Ethical issue in animal experimentation. Bull Acad Natl Med 193: 1737-1746, 2009 (In French).

11. Supavekin S, Zhang W, Kucherlapati R, Kaskel FJ, Moore LC and Devarajan P: Differential gene expression following early renal ischemia/reperfusion. Kidney Int 63: 1714-1724, 2003.

12. Zhang H, Bai H, Yi Z, He X and Mo S: Effect of stem cell factor and granulocyte-macrophage colony-stimulating factor-induced bone marrow stem cell mobilization on recovery from acute tubular necrosis in rats. Ren Fail 34: 350-357, 2012.

13. Martino M, Console G, Irrera G, et al: Harvesting peripheral blood progenitor cells from healthy donors: retrospective comparison of filgrastim and lenograstim. J Clin Apher 20 129-136, 2005

14. Booz GW and Baker KM: Molecular signaling mechanisms controlling growth and function cardiac fibroblasts. Cardiovase Res 30: 537-543, 1995.

15. Fernandes NM, Pinto Pdos S, Lacet TB, et al: APACHE II and ATN-ISS in acute renal failure (ARF) in intensive care unit (ICU) and non-ICU. Rev Assoc Med Bras 55: 434-441, 2009 (In Portugese)

16. Clark E, Molnar AO, Joannes-Boyau O, et al: High-volume hemofiltration for septic acute kidney injury: a systematic review and meta-analysis. Crit Care 18: R7, 2014.

17. Liu N, Han G, Cheng J, Huang J and Tian J: Erythropoietin promotes the repair effect of acute kidney injury by bone-marrow mesenchymal stem cells transplantation. Exp Biol Med (Maywood) 238: 678-686, 2013.

18. Le Blanc K and Pittenger M: Mesenchymal stem cells: progress toward promise. Cytotherapy 7: 36-45, 2005.

19. Deng Z, Yang C, Deng H, et al: Effects of GM-CSF on the stem cells mobilization and plasma $C$-reactive protein levels in patients with acute myocardial infarction. Int J Cardiol 113: 92-96, 2006.

20. Banerjee M, Kumar A and Bhonde RR: Reversal of experimental diabetes by multiple bone marrow transplantation. Biochem Biophys Res Commun 328: 318-325, 2005.

21. Burt R, Pearce W, Luo K, et al: Hematopoietic stem cell transplantation for cardiac and peripheral vascular disease. Bone Marrow Transplant 32 Suppl 1: S29-S31, 2003.

22. Charbord P: Bone marrow mesenchymal stem cells: historical overview and concepts. Hum Gene Ther 21: 1045-1056, 2010

23. Fu S and Liesveld J: Mobilization of hematopoietic stem cells Blood Rev 14: 205-218, 2000.

24. Wojakowski W and Tendera M: Mobilization of bone marrow-derived progenitor cells in acute coronary syndromes. Folia Histochem Cytobiol 43: 229-232, 2005.

25. Powell TM, Paul JD, Hill JM, et al: Granulocyte colony-stimulating factor mobilizes functional endothelial progenitor cells in patients with coronary artery disease. Arterioscler Thromb Vasc Biol 25: 296-301, 2005

26. Zhang JJ, Yi ZW, Dang XQ, He XJ and Wu XC: Mobilization effects of SCF along with G-CSF on bonemarrow stem cells and endothelial progenitor cells in rats with unilateral ureteral obstruction. Zhongguo Dang Dai Er Ke Za Zhi 9: 144-148, 2007 (In Chinese).

27. Da Silva CA, Reber L and Frossard N: Stem cell factor expression, mast cells and inflammation in asthma. Fundam Clin Pharmacol 20: 21-39, 2006
28. Li B, Berman J, Tang JT and Lin TJ: The early growth response factor-1 is involved in stem cell factor (SCF)-induced interleukin 13 production by mast cells, but is dispensable for SCF-dependent mast cell growth. J Biol Chem 282: 22573-22581, 2007.

29. Han JY, Goh RY, Seo SY, et al: Cotransplantation of cord blood hematopoietic stem cells and culture-expanded and GM-CSF-/SCF-transfected mesenchymal stem cells in SCID mice. J Korean Med Sci 22: 242-247, 2007.

30. Shi Q, Hodora V, Butler SD, et al: Differential bone marrow stem cell mobilization by G-CSF injection or arterial ligation in baboons. J Cell Mol Med 13: 1896-1906, 2009.

31. Lennartsson J, Shivakrupa R and Linnekin D: Synergistic growth of stem cell factor and granulocyte macrophage colony-stimulating factor involves kinase-dependent and -independent contributions from c-Kit. J Biol Chem 279: 44544-44553, 2004.

32. Carter BZ, Milella M, Altieri DC and Andreeff M: Cytokine-regulated expression of survivin in myeloid leukemia. Blood 97: 2784-2790, 2001

33. Duarte RF and Franf DA: The synergy between stem cell factor (SCF) and granulocyte colony-stimulating factor (G-CSF): Molecular basis and clinical relevance. Leuk Lymphoma 43: 1179-1187, 2002

34. Czekanska EM, Ralphs JR, Alini M and Stoddart MJ: Enhancing inflammatory and chemotactic signals to regulate bone regeneration. Eur Cell Mater 28: 320-334, 2014.

35. Liu N, Patzak A and Zhang H: CXCR4-overexpressing bone marrow-derived mesenchymal stem cells improve repair of acute kidney injury. Am J Physiol Renal Physiol 305: F1064-F1073, 2013.

36. Zhang W, Zhu C, Wu Y, et al: VEGF and BMP-2 promote bone regeneration by facilitating bone marrow stem cell homing and differentiation. Eur Cell Mater 27: 1-12, 2014.

37. Yueyi C, Xiaoguang H, Jingying W, et al: Calvarial defect healing by recruitment of autogenous osteogenic stem cells using locally applied simvastatin. Biomaterials 34: 9373-9380, 2013.

38. Illien-Jünger S, Pattappa G, Peroglio M, et al: Homing of mesenchymal stem cells in induced degenerative intervertebral discs in a whole organ culture system. Spine (Phila Pa 1976) 37: 1865-1873, 2012

39. Chen QQ, Yan L, Wang CZ, et al: Mesenchymal stem cells alleviate TNBS-induced colitis by modulating inflammatory and autoimmune responses. World J Gastroenterol 19: 4702-4717, 2013.

40. Ponte AL, Ribeiro-Fleury T, Chabot V, et al: Granulocyte-colony-stimulating factor stimulation of bone marrow mesenchymal stromal cells promotes $\mathrm{CD} 34^{+}$cell migration via a matrix metalloproteinase-2-dependent mechanism. Stem Cells Dev 21: 3162-3172, 2012.

41. Geutskens SB, Andrews WD, van Stalborch AM, et al: Control of human hematopoietic stem/progenitor cell migration by the extracellular matrix protein Slit3. Lab Invest 92: 1129-1139, 2012.

42. Lin F, Cordes K, Li L, et al: Hematopoietic stem cells contribute to the regeneration of renal tubules after renal ischemia-reperfusion injury in mice. J Am Soc Nephrol 14: 1188-1199, 2003

43. Humphreys BD: Kidney injury, stem cells and regeneration. Curr Opin Nephrol Hypertens 23: 25-31, 2014.

44. de Almeida DC, Donizetti-Oliveira C, Barbosa-Costa P, Origassa CS and Câmara NO: In search of mechanisms associated with mesenchymal stem cell-based therapies for acute kidney injury. Clin Biochem Rev 34: 131-144, 2013.

45. Li BC, Liu XF, Zhang Y, Sun LJ, Cui RL and Cheng T: Empirical study of bone marrow stem cells participating in the recovery acute tubular necrosis in mice. Zhonghua Shen Zang Bing Za Zhi 22: 664-668, 2006 (In Chinese)

46. Mahmoud K, Opelz G, Pelzl S, et al: Evaluation of hepatocyte growth factor as a sensitive marker for early detection of acute renal allograft rejection. Transplantation 83: 1035-1040, 2007.

47. Grzelak P, Szymczyk K, Strzelczyk J, et al: Perfusion of kidney graft pyramids and cortex in contrast-enhanced ultrasonography in the determination of the cause of delayed graft function. Ann Transplant 16: 48-53, 2011.

48. Juarez JC, Manuia M, Burnett ME, et al: Superoxide dismutase 1 (SOD1) is essential for $\mathrm{H} 2 \mathrm{O} 2$-mediated oxidation and inactivation of phosphatases in growth factor signaling. Proc Natl Acad Sci USA 105: 7147-7152, 2008. 